Die

\title{
allgemeine chirurgische
}

\section{Pathologie und Therapie}

in

funfzig Vorlesungen.

Ein Handbuch für Studirende und Aerzte

von

\section{Dr. Theodor Billroth.}

Profersor der Chirurgie in Wien.

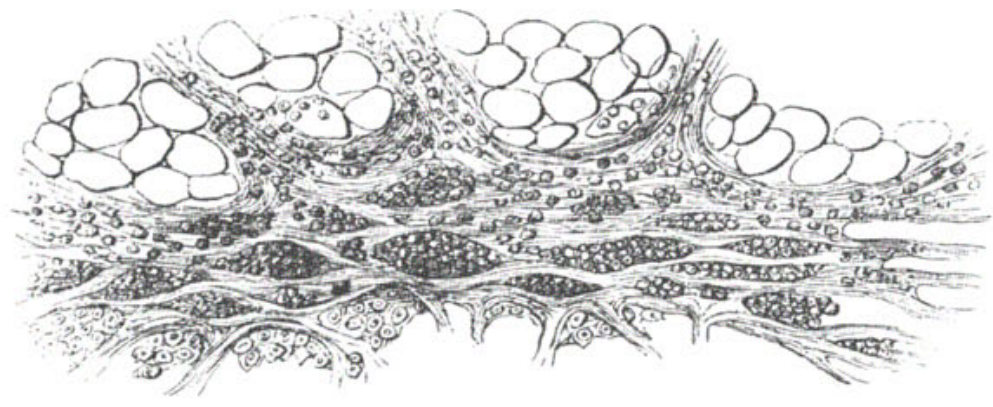

Dritte überarbeitete und mit Holzschnitten vermehrte Auflage.

$$
\text { Berlin. }
$$

Druck und Verlag von Georg Reimer. 1868. 
Die Uebersetzung in andere Sprachen wird vorbehalten. 